Article

\title{
Eager to Develop Sustainable Business Ideas? Assessment through a New Business Plan (BP4S Model)
}

\author{
Paulo Lopes Henriques *(D), Pedro Verga Matos (D) and Helena Mateus Jerónimo (D) \\ Advance/CSG, ISEG School of Economics and Management, Universidade de Lisboa, 1200-781 Lisbon, Portugal; \\ pvmatos@iseg.ulisboa.pt (P.V.M.); jeronimo@iseg.ulisboa.pt (H.M.J.) \\ * Correspondence: lopeshen@iseg.ulisboa.pt
}

check for

updates

Citation: Henriques, P.L.; Matos, P.V.; Jerónimo, H.M. Eager to Develop Sustainable Business Ideas? Assessment through a New Business Plan (BP4S Model). Sustainability 2022, 14, 1030. https://doi.org/ $10.3390 /$ su14021030

Academic Editors: Tjiptono Fandy and Chandra Yanto

Received: 6 December 2021

Accepted: 11 January 2022

Published: 17 January 2022

Publisher's Note: MDPI stays neutral with regard to jurisdictional claims in published maps and institutional affiliations.

Copyright: (C) 2022 by the authors. Licensee MDPI, Basel, Switzerland. This article is an open access article distributed under the terms and conditions of the Creative Commons Attribution (CC BY) license (https:// creativecommons.org/licenses/by/ $4.0 /)$.

\begin{abstract}
This article presents the BP4S (Business Plan for Sustainability), which builds on the literature about business models, as an innovation that considers sustainability as a characteristic of a business. Sustainability becomes the objective of business instead of being an attribute of business. This article also proposes the Global Sustainability Project Index (GSPI) as a metric to measure the effect of a business venture on sustainability to help with the decision-making on the viability of a project in supporting the pillars of sustainability. Additionally, a collection of indicators for the 3Ps of sustainability (planet, people, and profit) is also an asset of this article.
\end{abstract}

Keywords: business plan; sustainable business; global sustainability project index; triple bottom line; BP4S

\section{Introduction}

Entrepreneurship is a dynamic process of vision, change, and creation [1]. It requires spending energy and passion on the creation and implementation of new ideas and creative solutions. The essential ingredients of this process are the willingness to take risks, the capacity to create an effective team and combine the necessary resources, and the vision to recognize opportunities where others see chaos [2]. Entrepreneurs are thus individuals who perceive an opportunity to create value and take risks in the development and creation of innovation to realize that opportunity [3]. Their initiatives are frequently judged by the paradigm of neoclassical economic theory that suggests that the primary obligation of the firm is to maximize profits for their shareholders [4] while subordinating its social and environmental goals to this primary obligation [5]. However, this paradigm does not fit reality anymore. Current reality challenges the entrepreneurs to walk a different path and to gain a holistic perspective on potential problems and pitfalls by balancing economic, ecological, and social goals [6]. They must evaluate all of these priorities when crafting their business and, for this, a business plan is crucial.

The literature on structures and models of business plans is vast, as well as the more specific one on sustainable business models (SBM) e.g., [7-9]. However, three major issues are preventing the emergence of the SBM field: construct clarity, boundary setting, and uncertainty about outcomes [7]. Instead of trying to solve the above-mentioned three issues, our proposal is to work on a clear way to predict outcomes. Thus, based on the usual structure of business plans, we have introduced changes and additions that fully capture the sustainability challenge when crafting a business plan. This approach is justifiable given the impact of what is known as the "lure to simplicity" [10], which encourages new entrepreneurs to remain with what they know, rather than risk the unknown.

This article presents a proposal for a coherent business plan based on the triple bottom line (TBL) of sustainability. This plan requires a measurement model that is based on a taxonomy of indicators and metrics of sustainability to evaluate the creation of value that, according to the TBL scenario, addresses the social and environmental dimensions and leverages them at the same level of an economic pillar. With this model, entrepreneurs can 
pursue a sustainable path and have a "win-win-win situation" [11,12] in which they contribute to the environment, to society, and are economically profitable and productive. All these dimensions are embedded at the design stage of the project and are thus proactively considered in the decision-making and integrated into the corporate strategy. By presenting a proposal for a business plan devoted to sustainability, we hope to contribute to a wide discussion about SBM and the ongoing debate on sustainability assessment metrics as well as establishing the basis for a real and timely orientation to business models devoted to sustainability.

This paper is organized as follows. In the first section, we present the importance of integrating the concept of sustainability into business plans, which supports our research question of the need to introduce changes into the existing business plans structures. In the next section we present our proposal for a business plan structure- the BP4S model. Finally, we compare our proposal with the literature on business plan structures in order to answer the formulated research question. Finally, the conclusions and limitations are presented.

\section{Business Sustainability and Business Plans}

Following the canonical definition of sustainable development by the Brundtland Report, Our Common Future [13], we understand business sustainability in this article as "the ability of firms to respond to their short-term financial needs without compromising their (or others') ability to meet their future needs" [14] (p.71). This concept is the application of sustainability at the micro-level of companies, as in effect companies are a major player in the process of sustainability. For companies, strategies, practices, and operations-in sum, their business model - all need to contribute to achieving the macro-goal of sustainable development. It is this root and focus, both on internal and external responsibility, as well as the short and long-term implications of a company's performance, that differentiates business (or corporate) sustainability from the corporate social responsibility approach [15]. Although differing points-of-view exist regarding the overlapping or separation of these two concepts in the literature $[15,16]$, this paper adopts the sustainability framework, whilst considering the importance of appraising business through a holistic and mutually reinforcing lens of social, environmental, and economic components in the long-term. Those components form the so-called "triple bottom line", a kind of triple helix for change and value creation, that combines economic growth, environmental quality, and social justice $[12,17]$. Studies have translated this approach into the three Ps-profit, planet, and people. Despite this tripartite structure, the three terms are not on equal footing. In fact, traditionally, the priority given to the profit pillar has overshadowed the planet and people dimensions, in particular the latter.

This paradigm has fueled the emergence of new organizational forms such as " $B$ corporations" [18] whose identity is formed by the objective of fulfilling both shareholder and stakeholder interests. This singular identity can help companies to distinguish themselves from the rest of the organizational landscape. B-corporations are the main form of a "conscious capitalism" [19], that is, one that is mindful, recognizable, and accountable for all its externalities and is in harmony with nature and communities. Some authors, e.g., [20] even propose that organizations operate currently in a 1.0 (focused on shareholder value management) or 2.0 business sustainability modes (focused on the triple bottom line) and that they should move up to 3.0 model: a "truly sustainable business" that can solve collective sustainability challenges and therefore create value for the common good. It adopts an "outside-in" approach. This perspective is in line with the grand challenges of the United Nations' Sustainable Development Goals (SDGs) - the world's holistic and integrated agenda for sustainable development [21,22].

Creating a business means investing resources-namely financial ones. To get these resources, a business must present a solid and coherent idea to potential investors [23]. According to Barrow, Barrow, and Brown [24] (p.10), "The business plan is the ticket of admission giving the entrepreneur or proposal champion the first and often only chance to impress prospective backers with the quality of the proposal". The literature offers 
abundant approaches about how to craft a business plan [25] that allows prospective backers to evaluate the business proposal and decide whether to invest or not to invest in the proposal (see Table 1). Traditionally, this decision was based on the evaluation of the return and the degree of risk involved in the investment [26]. The emphasis of traditional business plans was the degree of risk that depended on the business capacity to generate cash flows, the presence of collateral security, the capability of the management team, the product or service, and the market [25].

Table 1. Business plan models and BP4S proposal.

\begin{tabular}{|c|c|c|c|c|}
\hline Kuratko Model [27] & Harvard Model [28] & $\begin{array}{l}\text { Deloitte \& Touche } \\
\text { Model [29] }\end{array}$ & $\begin{array}{l}\text { Ernst \& Young } \\
\text { Model [30] }\end{array}$ & BP4S \\
\hline Executive Summary & Executive Summary & Executive Summary & Executive Summary & Executive Summary \\
\hline $\begin{array}{c}\text { Company history and } \\
\text { entrepreneurs' } \\
\text { presentation }\end{array}$ & Business Description & $\begin{array}{c}\text { Company, Strategy and } \\
\text { Management Team }\end{array}$ & Concept & $\begin{array}{c}\text { Business outline, based } \\
\text { on the sustainability } \\
\text { principles (3P's) }\end{array}$ \\
\hline Business description & $\begin{array}{c}\text { Environmental } \\
\text { Analysis }\end{array}$ & $\begin{array}{l}\text { Management and } \\
\text { Organization }\end{array}$ & $\begin{array}{l}\text { Market and } \\
\text { Competition }\end{array}$ & \multirow{2}{*}{$\begin{array}{c}\text { Market and } \\
\text { Competition Analysis } \\
\text { Strategy outline based } \\
\text { on the 3P's }\end{array}$} \\
\hline Market & Sectorial Analysis & $\begin{array}{l}\text { Market and } \\
\text { Competition }\end{array}$ & Business Strategy & \\
\hline Marketing & Competitive Analysis & Products/Services & Operational Strategy & Resources consumption \\
\hline Operations & Market Analysis & Marketing and Sales & $\begin{array}{l}\text { Management and } \\
\text { Organization }\end{array}$ & Funding \\
\hline Financial projections & Marketing Plan & Financial Information & Financial Information & $\begin{array}{l}\text { Prospective } \\
\text { Performance }\end{array}$ \\
\hline Risk Analysis & Operational Plan & & Future Prospects & $\begin{array}{l}\text { Global Sustainability } \\
\text { Project Index }\end{array}$ \\
\hline $\begin{array}{l}\text { Business management } \\
\text { and control model }\end{array}$ & Management Team & & Required funds & $\begin{array}{c}\text { Risk Assessment and } \\
\text { Analysis }\end{array}$ \\
\hline \multirow[t]{2}{*}{ Calendar } & Financial Plan & & Risk Analysis & \\
\hline & Calendar & & & \\
\hline
\end{tabular}

Globally, as a management tool, the business plan can be used to identify and establish business objectives, develop strategy, create appropriate structures, define activities and responsibilities, and measure potential results; all of these metrics could be very important to communicate to future employers, suppliers, and potential investors [31]. The relevance of writing and implementing a business plan can be understood under the assumption that its elaboration has a positive effect on the realization of a business and the success of a company (new or already established) [32]. Although there is extensive research in the literature on identifying the main factors of success associated with the creation of new companies, the results of those studies are contradictory. An evaluation is needed on the effect that the existence and the respective quality of a business plan has on the survival of a company. According to Fernández-Guerrero, Revuelto-Taboada, and SimónMoya [33], the execution of a business plan with economic and financial viability is not in itself a guarantee of the company's survival. But several authors identify a positive relationship between the construction and implementation of a business plan and the respective company's performance, e.g., [32], especially against companies that choose not to carry out the aforementioned plan, e.g., [34].

In summary, a business plan is undoubtedly an important roadmap of a possible future scenario that can help improve the company's chances of success [35,36]. Therefore, companies that fail to embrace sustainability concerns in their strategy put their future at risk [37]. Using broader sustainable criteria—and not only financial ones-has become increasingly important and necessary to compete for investors' attention, respond to a 
radically different market reality, ensure reputation and a long-term competitive advantage, and to comply with the sustainability of resources to the satisfaction of regulators, employees, customers, and society at large [38,39]. A business plan that integrates a sustainability lens expands the focus from the financial performance and shareholder interests to the long-term social and environmental effects as well as a multi-stakeholder perspective. Such a plan recognizes the need to create value for all groups involved in the company and the natural environment, while emphasizing the need to go beyond profit maximization which is what stakeholder theory argues [40-42].

As a general proposal, Gabler, Panagopoulos, Vlachos, and Rapp [43] offer a three-level environmentally sustainable business plan. Companies must thus embrace a philosophy of environmental sustainability (normative level that includes the beliefs and attitudes of an organization seen through employees and managers but also in the mission statement). Companies must also develop specific strategies that convey the normative philosophy of the organization (strategic management level). Finally, they should operationalize, execute, and measure the performance of those strategies (operational level). Within this normative and strategic realm, one can reconceptualize business models around a "value triangle", as proposed by Biloslavo, Bagnoli, and Edgar [44], which brings to the fore elements that truly add value and would otherwise be hidden despite being crucial to business growth. Based on an eco-critical approach, this new framework represents how a company "co-creates and co-delivers value with its stakeholders within a circular value system and capture some economic value from it" [44] (p.755). Despite the current advances in this field, there is still room to explore this co-creation and values at a more operational level. Sustainable business plans may thus be the vehicle to change the mindset and practice on the process of evaluating business ideas.

Accordingly, our research question is: What changes and additions should a business plan that fully considers sustainability adopt compared with the traditional structure of a business plan? To answer this research question, we take as a departing point the important insights provided by Rauter, Jonker, and Baumgartner [45] and Laasch [46]. The former argues that businesses which incorporate sustainability dimensions do not differ substantially from traditional ones, but require specific adaptations and extensions. The latter suggests that two or more heterogeneous value logics can coexist in the some business (the sustainability business models' heterogeneous value logics). Grounded on these inputs, we analyzed the structures of traditional business plans and reviewed the literature on the 3Ps and their impacts on businesses in order to propose a new model, the BP4S, which will be presented in the next section.

\section{The Need for a Business Plan That Fully Considers Sustainability: The BP4S Proposal}

\subsection{The Traditional Business Plan Structure}

There are several approaches to writing a business plan such as those proposed by Harvard [28], Ernst \& Young [30], or Kuratko [27] (Table 1). According to Harvard [28] and Kuratko [27], entrepreneurs do not have to strictly follow a predetermined model but doing so will help them to define how they wish to present the information to their target audience. Although Vesper [47] notes that all potential investors will be interested in core problems such as feasibility, potential profit, negative risks, or life cycle to some degree, they are increasingly approaching new projects from the perspective of the three pillars of sustainability (planet, people, and profit) [48,49].

All traditional models for business plans analyze the impact of changes in the main project parameters on business performance based mainly on financial metrics (e.g., payback, net present value (NPV), or internal rate of return (IRR)) as well as a risk analysis (scenario or sensitivity analysis). This approach implicitly assumes that the entrepreneurs and/or investors are only concerned with an adequate return on invested capital. However, a new approach to business plans is clearly needed in a context where investors are increasingly considering nonfinancial perspectives (social, environmental), where performance can be seen in three integrated and complementary approaches (people, planet, and profit), 
where risks can be identified, assessed, and managed by also considering non-financial elements and where public policies also include concerns for sustainability (e.g., the Green Deal at the European Union level [50]). In addition, specifically for new projects (start-ups), new performance metrics are needed that include all three strands and are reliable, easy to measure, and technically robust.

\subsection{The Needed Change to Capture the Sustainability Dimensions}

A vast literature exists on the theme of sustainable business plans to overcome the neglect of the social and environmental dimensions when assessing a business's performance, e.g., $[9,44,51-53]$.

One of the well-known proposals for a sustainable business plan is the TLBMC, which stands for Triple Layered Business Model Canvas (Joyce and Paquin [54] that is based on the works of Osterwalder and Pigneur [55] and Osterwalder, Pigneur, and Tucci [56]). This TLBMC was presented with the aim of "explicitly integrating environmental and social impacts through additional business model layers that align directly with the original economic-oriented canvas" [54] (p.1474). To achieve that, Joyce and Paquin proposed a model involving 27 key building blocks: the first group of nine addresses economic issues, the second group addresses the environmental life cycle, and the remaining group of nine addresses societal issues. The objective is to achieve vertical and horizontal coherence between the blocks in each layer and between the layers in order to reach "a clear understanding and align an organization's actions towards sustainability at strategic business model level" [54] (p.1476).

In our view, this approach has two problems. First, it is highly complex, which means that new ventures and small entrepreneurs will not be able to fully use this approach. As an example of this difficulty, Marcovecchio and Nambalirwa Kuwana [57] compare the TLBMC of two multinational firms and find several inconsistencies both vertically and horizontally. Second, it affects the impact of the already mentioned "lure to simplicity" [10]. To overcome these difficulties, it is necessary to develop a proposal for the evaluation of business plans where sustainability dimensions are effectively considered. Such a proposal should be grounded on adding a sustainability dimension to the models already widely used. In this way the needed changes are inserted and in the same way the investors are kept in "their known world".

Having as a background the most used business plan structures, the BP4S proposes a model in which the business plan and its evaluation form a harmonious whole where the business is foreseen and evaluated according to its sustainability option. In this way, the sustainability dimensions are not understood as restrictions to the business or as politics or legal regulations but rather are highly recommended because they generate value to the business and respond to all stakeholders' needs. The last column of Table 1 presents the outline of the sections of such a model for formatting and writing a business plan based on sustainability concerns. As can be seen in Table 1, the BP4S structure is not considerably different from the other models currently in use. The main differences are the clear orientation towards sustainability when conceptualizing different sections to present the business idea, where emphasis is given to the sustainability dimension (see, for example, the titles of each section, or all the new sections of resources consumption, or the global sustainability project index). The complete structure is presented in detail in the following section in order to see the full picture of what is new in BP4S.

The main concern is to develop a business plan in which the sustainability dimension is a characteristic of the business and actively contributes to the creation of value whatever the business activity. Thus, the BP4S model is structured with seven sections (Figure 1).

The BP4S building blocks explain the business idea and present how it will create value to the stakeholders. In particular, they show how the global sustainability index affects sustainability. The development of each building block is presented in the next section. 


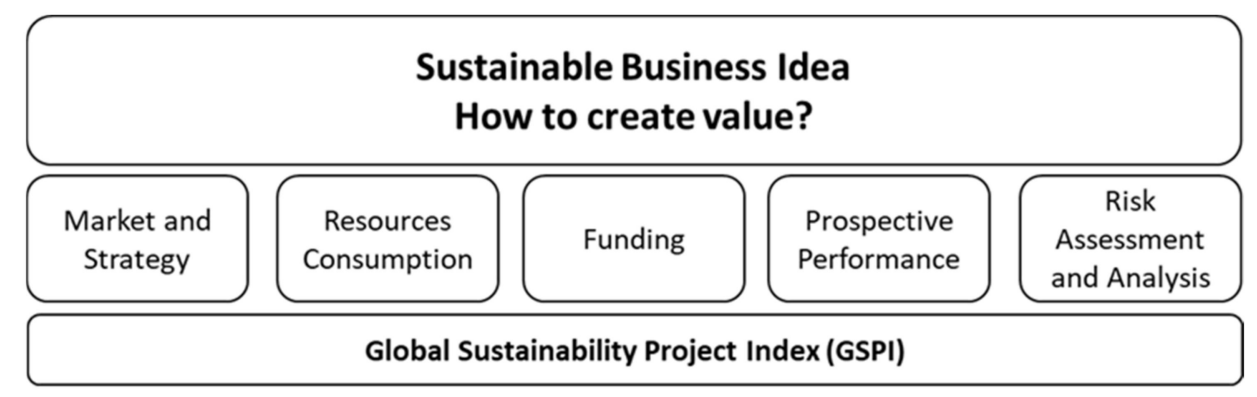

Figure 1. BP4S building blocks.

\subsection{Detailed Analysis of BP4S Sections}

Presenting a business plan should begin with an executive summary that is an opportunity for entrepreneurs to make a memorable presentation.

Executive Summary: The executive summary should highlight what is distinctive in the plan: What is the sustainable idea that supports the business? What are the core competencies that will guarantee the success of the business? What will be the main results in the short, medium, and long terms? Why does this business deserve funding?

After crafting a solid and memorable executive summary, the plan needs to detail the information that is the base to understand the new business and the choices made to accomplish value. The BP4S is divided into seven sections. From those, the first and the last one are considered fundamental given their importance. The first one explains the sustainable business idea and the last one proposes an index to measure the sustainability impact of the project.

The first section-The Sustainable Business Idea-describes the business by emphasizing: (a) how the business idea is sustainable or contributes to increasing the sustainability levels in the industry or region; (b) how the value will be created; (c) what distinctive competencies does the project have that will guarantee success (e.g., approach to customers, use of resources, type of products, innovation, etc.); (d) who are the promoters and what value do they add to the project; and (e) what legal structure will be followed by the business.

The second section - the Market and Strategy Outline based on the 3Ps-presents in detail the knowledge that the business has accumulated in the industry where the project will be developed. This knowledge is mainly related to the market and the competition analysis and to the strategy that will be put into practice to be successful in that market and industry. Further, the market and the competition analysis should emphasize the way in which the new project fills the gap in terms of sustainable dimensions (Table 2).

Table 2. Market and Competition Analysis.

\section{Market and Competition Analysis}

Should present in detail the knowledge accumulated on the industry where the project will be developed.

1. Describe the industry where the new venture will operate

2. Describe the target markets including major characteristics and segments
What are the sustainable practices already in use?

Who are the players and their activities?

Who are the major customers?

How are the sustainable practices valued by the market and how are they implemented?

What needs are being or not being satisfied by the actual players?

Importance of localization and its impact on the business.

How the purchase decisions are made (main determinants).

Market size in terms of number of customers, sales volume for the products or services that are similar to the ones offered in this project, growth of sales in the past 5 to 10 years. 
Table 2. Cont.

\begin{abstract}
3. What are the products or services offered in terms of the main features and sustainability impacts?

Explain the concept of product or service that is being offered.

How is sustainability a part of this concept?
\end{abstract}
4. Describe the pricing and margins in the market including the rationale and the connection with the sustainability practices.
Price objectives and gross margins
Detail how sustainable practices affect the pricing policy and gross margin.

5. What was the market penetration and evolution of the market position of the main competitors?

Number of customers/market share/geographical coverage and rationale

Evolution of the market in the past 5 to 10 years

Associate the evolution with changes in the product or service concept.

6. Describe the methods used to gain the
customers.

The main sale arguments and their rationale

Communications channels

7. What are the market constraints? Present an analysis that details the main threats or

Detail the barriers to entry into the market (investment required, technology, key certifications, patents, key knowledge, customer inertia due to loyalty, among others) requirements to operate in this market.

Detail legal and regulatory implications to the new venture

After the snapshot of the actual market situation, one should present how the new business will integrate into that market and the reasons why it deserves to be funded. Table 3 presents the information that must be gathered to craft a strategy outline for the new business to enter the market.

Table 3. Strategy outline.

\begin{abstract}
The strategies designed here should disclose the proponents' ability to develop the management activities needed for a successful entry into the market. The design of strategies must consider the implementation of sustainability practices that simultaneously meet the requirements of efficiency and effectiveness as well as having an impact on the three pillars of sustainability. (It is Advised to use the collection of sustainable measures offered in this article.)
\end{abstract}

What need will to be satisfied by the new concept?

Describe the product or service in terms of benefits, ability to meet needs, competitive advantages, sustainable impacts, and present stage of development.

1. Detail the products or services that Describe the product or service's life cycle by explaining what the current stage of the product or service is and what factors can affect that position.

will be offered in the market and the future developments.

Present the research and development (R\&D) activities that are connected to the actual and future level of development of the product or service as well as the legal protections that are or might be put in place.

Detail the expected returns from future R\&D activities.

Detail the sustainable practices that will occur that will make the difference for the client in terms of:

(a) the marketing penetration strategy, the growth strategy, and what distribution channels will be used;

2. How will sales be achieved?

(b) the argument for the sale and its rationale;

(c) the communication strategy that will be used to attract customers through the arguments for the sale in terms of promotion, advertising, public relations, and communication channels, among others;

(d) the sales strategy that will be used in terms of sales force (internal or external), efforts to recruit, train, and compensate;

(e) the sales activities that will be used.

Describe the production and delivery procedures that will be used and their present and future capabilities. Be specific about the sustainable practices that will be used regarding these procedures and their expected effects.

3. How are operations expected to work to achieve the objective.

Explain the operating competitive advantages (techniques, experience, economies of scale, etc.) in terms of their source and impact on the venture.

Describe who will be the principal suppliers (the ones that will supply the critical elements of production of your product or service) in terms of their capacity to guarantee the provisioning and the type of contractual arrangements that will be used to support the relationship. 
Table 3. Cont.

\begin{tabular}{ll}
$\begin{array}{l}\text { 4. Describe the pricing and margins } \\
\text { expected including the rationale and } \\
\text { the connection with the sustainability } \\
\text { practices. }\end{array}$ & $\begin{array}{l}\text { Price objectives and gross margins expected } \\
\text { Detail how sustainable practices will affect the pricing policy and gross margin. }\end{array}$ \\
\hline $\begin{array}{l}\text { 5. What will be the expected market } \\
\text { penetration and evolution of the } \\
\text { market position? }\end{array}$ & $\begin{array}{l}\text { Number of customers/market share/geographical coverage and rationale } \\
\text { Evolution of the market in the next } 5 \text { to } 10 \text { years }\end{array}$ \\
$\begin{array}{ll}\text { 6. Present the main results related to } \\
\text { the market test }\end{array}$ & $\begin{array}{l}\text { Reaction from potential customers } \\
\text { Importance given to the product or service concept (emphasis on the sustainable features) }\end{array}$ \\
$\begin{array}{l}\text { Willingness to purchase at different price levels } \\
\text { description of the proximal } \\
\text { competitors, its proposals, and the } \\
\text { prospective retaliation to the new } \\
\text { entry into the market. }\end{array}$ & $\begin{array}{l}\text { Characterize the proximal competitors: type of operation, market share, value offer, } \\
\text { potential of retaliation, and the importance of this market to them. }\end{array}$ \\
$\begin{array}{l}\text { What do they offer in terms of sustainability practices or claims? } \\
\text { Present the strengths and the weakness of those competitors in terms of their ability to } \\
\text { satisfy the customers, financial resources, key assets (human, technological, geographical, } \\
\text { reputation, or other that are important in the market). }\end{array}$
\end{tabular}

In the third section-Resource Consumption-resource consumption must be anticipated and highlighted in the project's functioning process. In particular, the plan must explain how the practices that are related to the three pillars of sustainability will be affected. This section should explain the differences introduced to the market by the new concept on each topic and the expected effects on the sustainability (see the Appendix A, Table A1 for a list of practices). The resource consumptions that should be addressed in detail are:

(a) the human resources in terms of number, capacities, competencies, gender, minorities, training and development, integration, and reward policy;

(b) the need for infrastructure like buildings, vehicles, and other installations considered relevant;

(c) the raw materials and others;

(d) the need for technology;

(e) the non-renewable materials;

(f) the renewable materials.

The fourth section-Funding - should present the amount of funds needed by the project and its sources, shareholders, debts, or investors (see Table 4). The entrepreneur should provide a fair explanation about the sources of funds, namely amounts; reason for use of that source; and a calendar related to the use of the funds. In this section, the importance to the project should be clear about the use of such sources of funds.

Table 4. Funding.

Description of the estimated amount of equity capital, and the type of associated securities (shares, quotas, etc.)

1. Shareholder funding Estimation of opportunity cost of equity (considering risk free remuneration, industry beta and market premium-CAPM)

Calendar of equity subscriptions

2. Funding using debt Description of the estimated amount and type of debt (bonds, bank loans, short term and long term.

Conditions of the loan (interest rate, schedule, and method of redemptions) or bond emission)

3. Funding using other Detailed description of other prospective national and/or international sources of capital (amount, financial resources public policies associated, financial conditions, commitments for the project, etc.)

The fifth section-Prospective Performance-presents quantified estimates of the operational effects, based on the options made and explained in the previous sections. 
Therefore, this section must offer a comprehensive budgeting of the new venture for each of the three pillars of sustainability and the expected performance for investors of the project (see Table 5).

Table 5. Prospective performance.

1. Measuring the prospective performance of the options made in the planet pillar (Pl)

2. Measuring the prospective performance of the options made in the people pillar (Pe).

3. Measuring the prospective performance of the options made in the profit pillar (Po).
Starting with the qualitative effects on the planet by having this new project in operation. It is important to detail the quantitative effects on the environment of at least 5 to 10 years of operation. Effects such as effluent production, quality of the air, recycling, consumption of nonrenewal materials, or renewable materials, etc.

Starting with the qualitative effects on people pillar by having this new project in operation. It is important to detail the quantitative effects of the options made on the people pillar of at least 5 to 10 years of operation. Effects such as welfare of the conditions of life of the community, gender equality, employment, education, employability, etc.

Detail the effects of the options in term of budgets for at least 5 to 10 years of operation; Based on the budgets done present the calculation of performance measures such as financial performance: NPV-Net Present Value or IRR-Internal Rate of Return.

The sixth section is to calculate the Global Sustainability Project Index (GSPI). Given the integrated perspective of the business plan and in order to allow a global evaluation of the quality of the proposed investment (considering the environmental, social, and economic components), an index is proposed as a global synthesis measure. The GSPI rates the expected future global performance by considering the three pillars together and by classifying the effect of each pillar with a metric from 1 to 5 for which $1=$ very weak effect and $5=$ very strong effect (Table 6). Naturally the proponents must classify each level of an effect by considering the surrounding conditions and justifying the classification. For example, consider a situation where a region does not have a sewage treatment system and waste waters are drained directly into a local river that in turn is a source of water for the community. If the project foresees the installation of a sewage treatment system that will not only treat the sewers of the project but also the sewers of the community, then the impact will be high both in the people pillar and in the planet pillar.

Table 6. Global Sustainability Project Index (GSPI).

Rate future global performance by considering each of the three pillars with the following metric:

1 to 5 where:

1 -very weak effect

2-weak effect

3 -average effect

4-strong effect

5-very strong effect

Regardless of the option used to calculate the GSPI, this must be justified by the presentation of the reasoning that led to the option that stresses the motives to use either of the options.
Rate the effect on each pillar by using the analysis of the prospective performance. The overall effect of the project on each of the pillars must be classified individually. Each classification must be duly justified considering the insertion of the project into the surrounding conditions using a simple or an elaborate approach to calculate the global index (GSPI):

(a) simple approach: calculate the mean of the ratings assigned to the effect of each pillar that assigns the same weight to each pillar; or

(b) elaborated approach: calculate the weighted mean of the ratings assigned to the effect of each pillar.

The two-step approach means the use of two techniques: the Delphi and the MACBETH tool:

(1) By using the Delphi technique, it is possible to select the relevant measures for evaluating the merit of the project (from a list that considers different indicators for each sustainability pillar (see Table A1);

(2) Grounded on the measures selected and through a MACBETH tool (Measuring Attractiveness by a Categorical-Based Evaluation Technique), it is possible to rate the effect of each pillar on of global value of the project (see Box A1).

Consequently, a combination of Delphi/MACBETH could be used to differently weight the ratings of the pillars to achieve the GSPI.

Summarizing, the overall value of a project will be:

$\mathrm{GSPI}=\left(\mathrm{W}_{\mathrm{o}}(\mathrm{Po})+\mathrm{W}_{\mathrm{e}}(\mathrm{Pe})+\mathrm{W}_{\mathrm{l}}(\mathrm{Pl})\right) / 100$

in which:

GSPI $=$ Global Sustainability Project Index

Po $=$ value in the profit pillar

$\mathrm{Pe}=$ value in the people pillar

$\mathrm{Pl}=$ value in the planet pillar

$\mathrm{Po}+\mathrm{Pe}+\mathrm{Pl}=100$ points

$\mathrm{W}$ (factor) weight 
The seventh section-Risk Assessment and Analysis—is based on the identification and measurement of main risks and uncertainties that may affect the bases of the business presented from Sections 1-4, and have an effect on the prospective performance (Section 5), considering throughout this approach the three pillars that characterize the BP4S approach. This analysis is done by using two different but complementary approaches-the sensitivity analysis and the scenario analysis (Table 7). For each change or set of changes the GSPI is recalculated. This analysis and the corresponding GSPI is a powerful tool for making decisions when comparing alternative scenarios and for preparing guidelines for the design and implementation of a risk management framework and process (such as, for example, by following the International Organization for Standardization's guidelines of 2018-ISO 31000).

Table 7. Risk assessment and analysis.

Calculation of the effect on performance indicators of changes in the chosen SDG metrics (ceteris paribus).

1. Sensitivity analysis The sensitivity analysis should be done by making three variations (e.g., $5 \%, 10 \%$, and 20\%) both positive and negative on chosen SDG metrics.

If possible, identify break even and security margin for each risk factor.

Creation of alternative scenarios associated with the various risk factors, duly justified, and if possible, associated with probability distributions.

Present distribution functions associated with the effect of risk factors on project performance if possible.

\section{Conclusions}

The number of companies making investments in high-impact sustainable projects is increasing, and investors are progressively prioritizing the sustainability effect of projects when making decisions [49]. According to Bernow, Klempner and Magnin [48], some of the world's largest institutional investors are integrating sustainability into their investment decision-making and are assessing new projects based on environmental, social, and economic criteria. For example, BlackRock, the world's largest asset manager, highlights that sustainability will be the company's new standard when investing, constructing portfolios, and managing risk [58]. This trend is also observable in venture capital investments whether in the early stages of seed capital, start-ups, or development capital. Thus, operating and measuring the performance of sustainability-centered business models is as important as their design and implementation. It is therefore necessary to develop analytical instruments that go beyond the traditional focus on the financial performance of projects. In fact, Lubin and Esty [59] argue that "developing metrics that allow companies to measure benefits and understand costs is essential to adapting and redesigning their strategy, as well as communicating results. And Wall Street will increasingly demand evidence that sustainability investments are generating returns" [59] (p.49). In other words, if executives can measure sustainability-centered business models' performance and results, then they will be able to operate and manage them and attract investors.

That is the purpose of the BP4S model. It is a tool grounded on the three P's considering sustainability as an opportunity and a driver for change and for value creation. Based on established models for business plans [27-30] that are predominantly focused on the existence (or not) of an adequate return on invested capital, BP4S broadens and deepens the analysis by considering:

a. the effects on the three pillars of sustainability (planet, people, and profit);

b. the effect on different stakeholders;

c. the medium- and long-term visions.

In addition, and only as an example, it provides a broad set of indicators that can be used by analysts and investors to measure the effects of the project on people, planet, and profit. As a concluding remark, the BP4S model invites prospective entrepreneurs and investors to prepare their sustainable businesses plans upstream, rather than consider sustainable options about how to get the business running. This is the main change and 
contribution provided by the BP4S model-the adoption of sustainability as a business philosophy, rather than considering sustainability to be a business enabler. Accordingly, $\mathrm{BP} 4 \mathrm{~S}$ is in effect a response to the evolving demands of capitalism and businesses, where economies, societies, and ecology all go hand-in-hand.

\section{Limitations and Further Research}

Grounded on the literature on sustainability and business plans, this work seeks to integrate both "worlds" into a framework which investors, entrepreneurs, and other stakeholders can all fully comprehend and assess. The practical application of this model has yet to be tested, although a high degree of confidence prevails regarding its applicability and its ability to produce relevant results. This confidence is rooted in two aspects. Firstly, the BP4S structure is based on well-known models, which are currently in use. Secondly, the new sections are user-friendly and highly intuitive. Nevertheless, this integrative model stills need to be validated by further research, similar to the treatment of previous proposals. This work aspires to initiate a line of discussion which fully integrates the need to do business with the need to be sustainable from the very beginning.

Author Contributions: Conceptualization, P.L.H., P.V.M. and H.M.J.; methodology, P.L.H., P.V.M. and H.M.J.; validation, P.L.H., P.V.M. and H.M.J.; formal analysis, P.L.H., P.V.M. and H.M.J.; investigation P.L.H., P.V.M. and H.M.J.; writing—original draft preparation, P.L.H., P.V.M. and H.M.J.; writingreview and editing, P.L.H., P.V.M. and H.M.J. All authors have read and agreed to the published version of the manuscript.

Funding: We gratefully acknowledge financial support from FCT-Fundação para a Ciência e Tecnologia (Portugal) through research grant UIDB/04521/2020.

Institutional Review Board Statement: Not applicable.

Informed Consent Statement: Not applicable.

Data Availability Statement: Not applicable.

Conflicts of Interest: The authors declare no conflict of interest.

\section{Appendix A}

Table A1. Collection of Indicators.

\begin{tabular}{|c|c|}
\hline SD Pillar & Indicators \\
\hline 旨 & 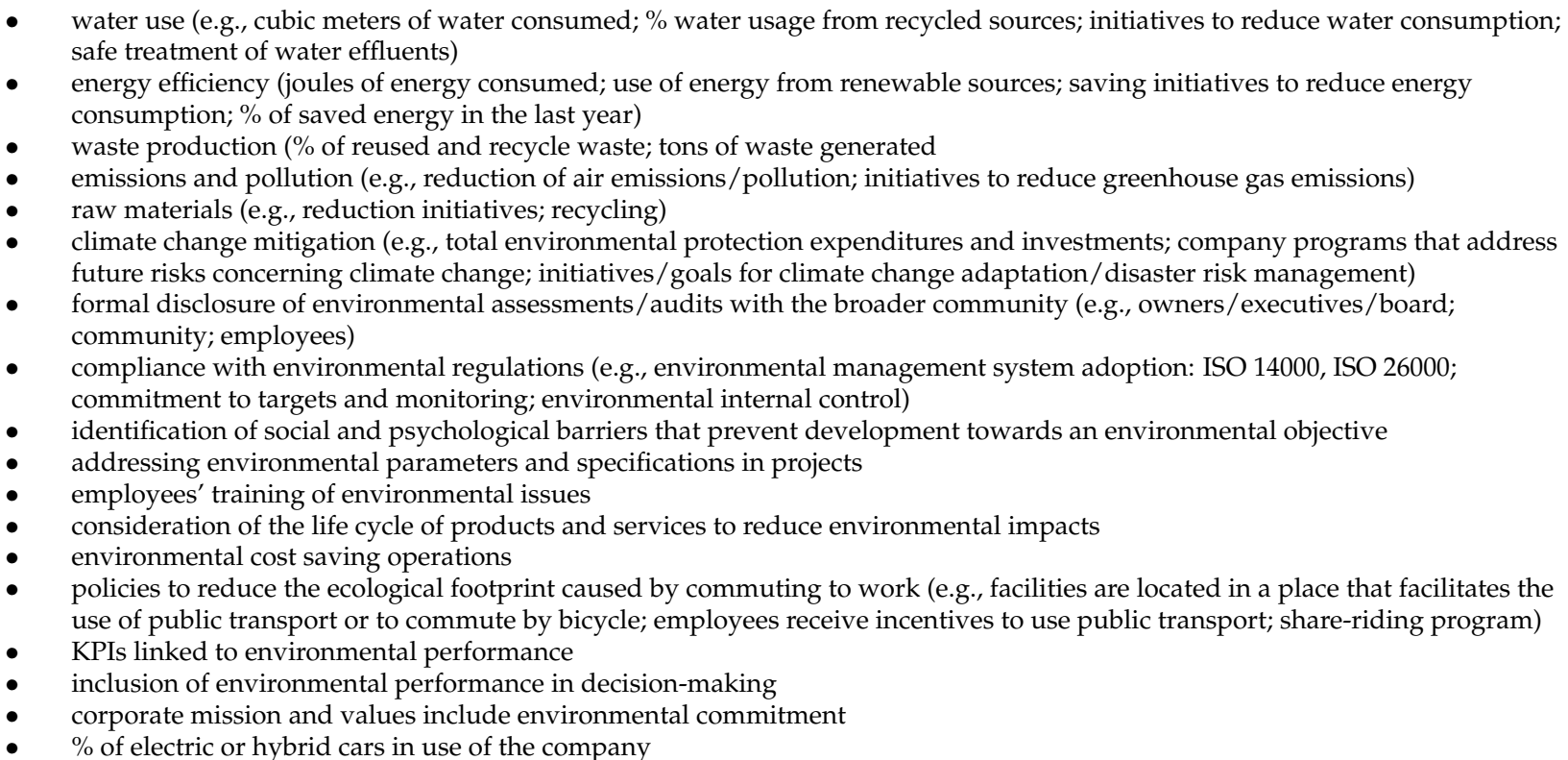 \\
\hline
\end{tabular}


Table A1. Cont.

\begin{tabular}{|c|c|}
\hline SD Pillar & Indicators \\
\hline 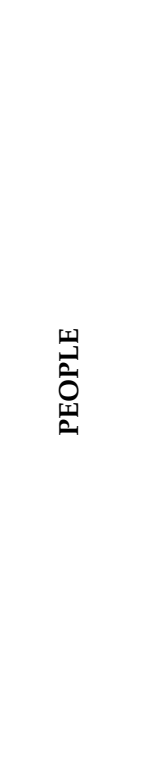 & 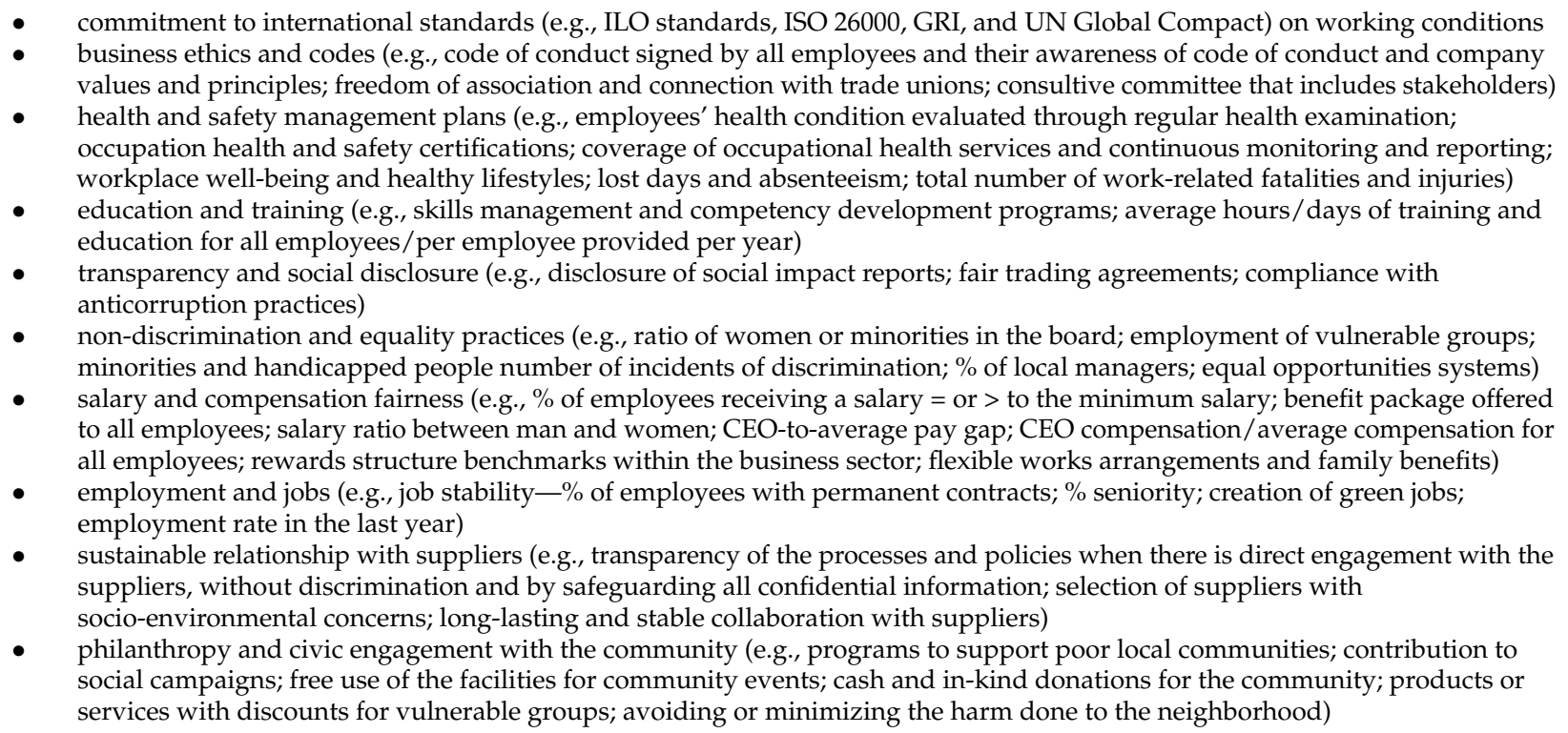 \\
\hline 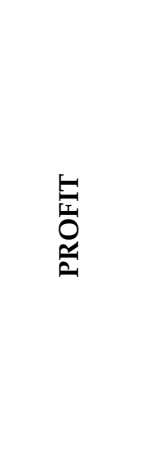 & $\begin{array}{l}\text { - } \\
\text { - } \quad \text { operats with employees (e.g., labor productivity per hour worked; rewards and benefits structure/cost; training; health and safety) } \\
\text { facilities costs and investments (e.g., development and impact of infrastructure investments; facility management } \\
\text { - } \quad \text { technologies/green buildings and services; development and impact of infrastructure investments) } \\
\text { - } \quad \text { legal compliance with economic and financial aspects } \\
\text { - } \quad \text { involvement in international markets } \\
\text { innovation management/new product development (research and development, productivity, and flexibility) } \\
\text { - } \quad \text { interaction with current and potential customers } \\
\text { - } \quad \text { supply chain collaboration practices } \\
\text { - } \quad \text { efficient data processing for decision-making practices } \\
\text { - } \quad \text { less bureaucracy for projects } \\
\text { targeted incentives to stakeholders }\end{array}$ \\
\hline
\end{tabular}

Source: adapted from [60-66].

Box A1. The Delphi Technique and the MACBETH Tool.

The Delphi technique seeks to capture the knowledge and experience of a panel of experts on a given subject to assist decision-making and informed forecasts [67]. This technique is structured in a way that enhances the positive aspects of group interaction (knowledge from various sources, creative synthesis, etc.), eliminating the negative aspects that may arise in this type of interactions (group pressure, dominance of some of the participants, etc.) [68].The Delphi technique can identify a wide set of interrelated variables as well as the multidimensional attributes common to most complex problems [67].

The MACBETH tool consists of a multi-criteria decision analysis (MCDA) approach that has the advantage of considering the subjective judgments of decision-makers on different options in relation to a set of evaluation criteria and translating these judgments into quantitative scores [69,70]. MACBETH is also an interactive methodology that, through a protocol of questions that compares elements two by two, uses semantic judgments regarding the differences in attractiveness of various options for each criterion [71,72], through seven semantic categories: null, very weak, moderate, strong, very strong, and extreme [71]. This process can quantify the attractiveness of the different options within each criterion as well as weigh the criteria among themselves [69-71]. This will allow the creation of merit indicators with intrinsic value (and not only relative value), allowing a much more realistic and less erroneous marking of the overall merit of a project. 


\section{References}

1. Kuratko, D.F.; Audretsch, D.B. Strategic entrepreneurship: Exploring different perspectives of an emerging concept. Entrep. Theory Pract. 2009, 33, 1-17. [CrossRef]

2. Allinson, C.W.; Chell, E.; Hayes, J. Intuition and entrepreneurial behavior. Eur. J. Work. Organ. Psychol. 2000, 9, 31-43. [CrossRef]

3. Hitt, M.A.; King, D.; Krishnan, H.; Makri, M.; Schijven, M.; Shimizu, K.; Zhu, H. Mergers and acquisitions: Overcoming pitfalls, building synergy, and creating value. Bus. Horiz. 2009, 52, 523-529. [CrossRef]

4. Stormer, F. Making the shift: Moving from "ethics pays" to an inter-systems model of business. J. Bus. Ethic. 2003, 44, 279-289. [CrossRef]

5. Freeman, E.R.; Gllbert, D.R., Jr. Business, ethics and society: A critical agenda. Bus. Soc. 1992, 31, 9-17. [CrossRef]

6. Kaplan, S. The Business Model Innovation Factory: How to Stay Relevant When the World is Changing; John Wiley \& Sons: Hoboken, NJ, USA, 2012.

7. Bocken, N.; Boons, F.; Baldassarre, B. Sustainable business model experimentation by understanding ecologies of business models. J. Clean. Prod. 2019, 208, 1498-1512. [CrossRef]

8. Bocken, N.; Samuel, P.; Short, W.; Rana, P.; Evans, S. A literature and practice review to develop sustainable business model archetypes. J. Clean. Prod. 2014, 65, 42-56. [CrossRef]

9. Lüdeke-Freund, F.; Dembek, K. Sustainable business model research and practice: Emerging field or passing fancy? J. Clean. Prod. 2017, 168, 1668-1678. [CrossRef]

10. Kalling, T. The lure of simplicity: Learning perspectives on innovation. Eur. J. Innov. Manag. 2007, 10, 65-89. [CrossRef]

11. De Prins, P.; van Beirendonck, L.; de Vos, A.; Segers, J. Sustainable HRM: Bridging theory and practice through the 'Respect Openness Continuity (ROC)'-model. Manag. Rev. 2014, 25, 263-284. [CrossRef]

12. Elkington, J. Towards the sustainable corporation: Win-win-win business strategies for sustainable development. Calif. Manag. Rev. 1994, 36, 90-100. [CrossRef]

13. Brundtland World Commission on Environment and Development. Report of the World Commission on Environment and Development: Our Common Future; United Nations: Geneva, Switzerland, 1987.

14. Bansal, P.; DesJardine, M.R. Business sustainability: It is about time. Strat. Organ. 2014, 12, 70-78. [CrossRef]

15. Ashrafi, M.; Adams, M.; Walker, T.R.; Magnan, G. How corporate social responsibility can be integrated into corporate sustainability: A theoretical review of their relationships. Int. J. Sustain. Dev. World Ecol. 2018, 25, 672-682. [CrossRef]

16. Ashrafi, M.; Magnan, G.M.; Adams, M.; Walker, T.R. Understanding the conceptual evolutionary path and theoretical underpinnings of corporate social responsibility and corporate sustainability. Sustainability 2020, 12, 760. [CrossRef]

17. Elkingon, J. 25 Years Ago I Coined the Phrase 'Triple Bottom Line': Here's Why It's Time to Rethink It. Harv. Bus. Rev. 2018, $25,2-5$. Available online: https:/ /hbr.org/2018/06/25-years-ago-i-coined-the-phrase-triple-bottom-line-heres-why-im-giving-up-on-it (accessed on 28 January 2021).

18. Kim, S.; Karlesky, M.J.; Myers, C.G.; Schifeling, T. Why Companies Are Becoming B Corporations. Harv. Bus. Rev. 2016, 17, 2-5. Available online: https://hbr.org/2016/06/why-companies-are-becoming-b-corporations (accessed on 16 November 2020).

19. Mackey, J.; Sisodia, R. Conscious Capitalism Is Not an Oxymoron. Harv. Bus. Rev. 2013, 1. Available online: https://hbr.org/2013 /01/cultivating-a-higher-conscious (accessed on 16 November 2020).

20. Dyllick, T.; Muff, K. Clarifying the meaning of sustainable business: Introducing a typology from business-as-usual to true business sustainability. Organ. Environ. 2016, 29, 156-174. [CrossRef]

21. Bebbington, J.; Unerman, J. Achieving the United Nations Sustainable Development Goals: An enabling role for accounting research. Account. Audit. Account. J. 2018, 31, 2-24. [CrossRef]

22. Mintrom, M.; Thomas, M. Policy entrepreneurs and collaborative action: Pursuit of the sustainable development goals. Int. J. Entrep. Ventur. 2018, 10, 153. [CrossRef]

23. Kuratko, R.M.; Hodgetts, D.F. Entrepreneurship: A Contemporary Approach; Dryden Press: New York, NY, USA, 1998.

24. Barrow, C.; Barrow, P.; Brown, R. The Business Plan Workbook, 4th ed.; Kongan: London, UK, 2001.

25. Mason, C.; Stark, M. What do investors look for in a business plan? A comparison of the investment criteria of bankers, venture capitalists and business angels. Int. Small Bus. J. 2004, 22, 227-248. [CrossRef]

26. Wynant, J.E.; Hatch, L. Banks and Small Business Borrowers; The Western Business School, University of Western Ontario: London, QC, Canada, 1991.

27. Kuratko, D.F. Entrepreneurship, 8th ed.; South Western, Cengage Learning: Mason, OH, USA, 2009.

28. Harvard Business School Publishing. Creating a Business Plan (Pocket Mentor Series), 1st ed.; Harvard Business Press Books: Boston, MA, USA, 2007.

29. Deloitte \& Touche. Writing an Effective Business Plan, 4th ed.; Deloitte \& Touche: London, UK, 2013.

30. Ernst \& Young. Guide to Producing of a Business Plan. 2009. Available online: http://group27.narod.ru/ucheba/files/EY_ Busines_Plan_Guide.pdf (accessed on 16 November 2020).

31. Brad, I. Business Plan: Major Management tools in developing of a business. Lucr. Stiintifice Manag. Agric. 2014, $16,214-217$.

32. Brinckmann, J.; Grichnik, D.; Kapsa, D. Should entrepreneurs plan or just storm the castle? A meta-analysis on contextual factors impacting the business planning-performance relationship in small firms. J. Bus. Ventur. 2010, 25, 24-40. [CrossRef]

33. Fernández-Guerrero, R.; Revuelto-Taboada, L.; Simón-Moya, V. The business plan as a project: An evaluation of its predictive capability for business success. Serv. Ind. J. 2012, 32, 2399-2420. [CrossRef] 
34. Burke, A.; Fraser, S.; Greene, F.J. The multiple effects of business planning on new venture performance. J. Manag. Stud. 2010, 47, 391-415. [CrossRef]

35. Frederick, H.; O'Connor, A.; Kuratko, D.F. Entrepreneurship: Theory/Process/Practice, 4th ed.; Cengage Learning: Melbourne, VIC, Australia, 2016.

36. Mazzarol, T.; Reboud, S. Entrepreneurship and Innovation-Theory, Practice and Context, 4th ed.; Springer: Berlin/Heidelberg, Germany, 2020.

37. Laszlo, C.; Zhexembayeva, N. Embedded Sustainability: The Next Big Competitive Advantage; Routledge: London, UK; New York, NY, USA, 2011.

38. Eccles, R.G.; Ioannou, I.; Serafeim, G. The Impact of a Corporate Culture of Sustainability on Corporate Behavior and Performance; No. W17950; National Bureau of Economic Research: Cambridge, MA, USA, 2012.

39. Eccles, R.G.; Strine, L.E.; Youmans, T. 3 Ways to Put Your Corporate Purpose into Action. Harv. Bus. Rev. 2020. Available online: https:/ /hbr.org/2020/05/3-ways-to-put-your-corporate-purpose-into-action (accessed on 28 January 2021).

40. Barton, M.; Schaefer, R.; Canavati, S. To be or not to be a social entrepreneur: Motivational drivers amongst American business students. Entrep. Bus. Econ. Rev. 2018, 6, 9-35. [CrossRef]

41. Freeman, E.R. Stakeholder Management: A Strategic Approach; Pitman: Boston, MA, USA, 1984.

42. Hörisch, J.R.; Freeman, E.; Schaltegger, S. Applying stakeholder theory in sustainability management: Links, similarities, dissimilarities, and a conceptual framework. Organ. Environ. 2014, 27, 328-346. [CrossRef]

43. Gabler, C.B.; Panagopoulos, N.; Vlachos, P.A.; Rapp, A. Developing an environmentally sustainable business plan: An international B2B case study. Corp. Soc. Responsib. Environ. Manag. 2017, 24, 261-272. [CrossRef]

44. Biloslavo, R.; Bagnoli, C.; Edgar, D. An eco-critical perspective on business models: The value triangle as an approach to closing the sustainability gap. J. Clean. Prod. 2018, 174, 746-762. [CrossRef]

45. Rauter, R.; Jonker, J.; Baumgartner, R.J. Going one's own way: Drivers in developing business models for sustainability. J. Clean. Prod. 2017, 140, 144-154. [CrossRef]

46. Laasch, O. Beyond the purely commercial business model: Organizational value logics and the heterogeneity of sustainability business models. Long Range Plan. 2018, 51, 158-183. [CrossRef]

47. Vesper, K.H. New Venture Mechanics, 1st ed.; Prentice Hall: Englewood Cliffs, NJ, USA, 1993.

48. Bernow, S.; Klempner, B.; Magnin, C. From 'Why' to 'Why Not': Sustainable Investing as the New Normal; McKinsey \& Company: London, UK, 2017.

49. Khan, M.; Serafeim, G.; Yoon, A. Corporate sustainability: First evidence on materiality. Account. Rev. 2016, 91, 1697-1724. [CrossRef]

50. Jaeger, C.; Mielke, J.; Schütze, F.; Teitge, J.; Wolf, S. The European Green Deal—More than climate neutrality. Intereconomics 2021, 2021, 99-107.

51. Evans, S.; Vladimirova, D.; Holgado, M.; van Fossen, K.; Yang, M.; Silva, E.A.; Barlow, C.Y. Business model innovation for sustainability: Towards a unified perspective for creation of sustainable business models. Bus. Strategy Environ. 2017, 26, 597-608. [CrossRef]

52. Johnson, M.P.; Schaltegger, S. Two decades of sustainability management tools for SMEs: How far have we come? J. Small Bus. Manag. 2016, 54, 481-505. [CrossRef]

53. Nosratabadi, S.; Mosavi, A.; Shamshirband, S.; Zavadskas, E.K.; Rakotonirainy, A.; Chau, K.W. Sustainable business models: A review. Sustainability 2019, 11, 1663. [CrossRef]

54. Joyce, A.; Paquin, R.L. The triple layered business model canvas: A tool to design more sustainable business models. J. Clean. Prod. 2016, 135, 1474-1486. [CrossRef]

55. Osterwalder, A.; Pigneur, Y. Business Model Generation: A Handbook for Visionaries, Game Changers, and Challengers; John Wiley \& Sons: Hoboken, NJ, USA, 2010.

56. Osterwalder, A.; Pigneur, Y.; Tucci, C.L. Clarifying business models: Origins, present, and future of the concept. Commun. Assoc. Inf. Syst. 2005, 16, 1. [CrossRef]

57. Marcovecchio, H.; Nambalirwa Kawuma, P. Sustainability-Centred Business Model Innovation: Learning from and Insights into How Sustainability Has Affected the Business Models of Nespresso and Starbucks. Master's Thesis, University of Lund, Lund, Sweeden, 2017. Available online: https://lup.lub.lu.se/student-papers/search/publication/8917350 (accessed on 16 November 2020).

58. BlackRock. Sustainability as BlackRock's New Standard for Investing (2020 Client Letter) BlackRock Global Executive Committee. 2020. Available online: https:/ / www.blackrock.com/corporate/investor-relations/2020-blackrock-client-letter (accessed on 11 December 2021).

59. Lubin, D.A.; Esty, D.C. The sustainability imperative. Harv. Bus. Rev. 2010, 88, 42-50.

60. B Corp. 2016. Available online: https:/ / bimpactassessment.net/pt-pt/start-b-impact-assessment (accessed on 16 November 2020).

61. Husgafvel, R.; Pajunen, N.; Päällysaho, M.; Paavola, I.-L.; Inkinen, V.; Heiskanen, K.; Dahl, O.; Ekroos, A. Social metrics in the process industry: Background, theory and development work. Int. J. Sustain. Eng. 2013, 7, 171-182. [CrossRef]

62. Ikram, M.; Zhang, Q.; Sroufe, R.; Ferasso, M. The social dimensions of corporate sustainability: An integrative framework including COVID-19 insights. Sustainability 2020, 12, 8747. [CrossRef] 
63. Montalbán-Domingo, L.; García-Segura, T.; Sanz, M.A.; Pellicer, E. Social sustainability criteria in public-work procurement: An international perspective. J. Clean. Prod. 2018, 198, 1355-1371. [CrossRef]

64. Rahdari, A.H.; Rostamy, A.A.A. Designing a general set of sustainability indicators at the corporate level. J. Clean. Prod. 2015, 108, 757-771. [CrossRef]

65. PWC-Pricewaterhouse Coopers Global. PwC's SDG Challenge 2019. 2019. Available online: https:/ /www.pwc.com/gx/en/ services/sustainability/sustainable-development-goals/sdg-challenge-2019.html (accessed on 16 November 2020).

66. Stanitsas, M.; Kirytopoulos, K.; Leopoulos, V. Integrating sustainability indicators into project management: The case of construction industry. J. Clean. Prod. 2021, 279, 123774. [CrossRef]

67. Gupta, U.G.; Clarke, R.E. Theory and applications of the Delphi technique: A bibliography (1975-1994). Technol. Forecast. Soc. Chang. 1996, 53, 185-211. [CrossRef]

68. Rowe, G.; Wright, G. The Delphi technique as a forecasting tool: Issues and analysis. Int. J. Forecast. 1999, 15, 353-375. [CrossRef]

69. Karande, P.; Chakraborty, S. A facility layout selection model using MACBETH method. In Proceedings of the 2014 International Conference on Industrial Engineering and Operations Management, Bali, Indonesia, 7-9 January 2014.

70. Mateus, R.J.G.; Bana e Costa, J.C.; Matos, P.V. Supporting multicriteria group decisions with MACBETH tools: Selection of sustainable brownfield redevelopment actions. Group Decis. Negot. 2017, 26, 495-521. [CrossRef]

71. Bana e Costa, C.A.; Chagas, M.P. A career choice problem: An example of how to use MACBETH to build a quantitative value model based on qualitative value judgments. Eur. J. Oper. Res. 2004, 153, 323-331. [CrossRef]

72. Bana e Costa, C.A.; de Corte, J.M.; Vansnick, J.C. On the Mathematical Foundations of MACBETH, Multiple Criteria Decision Analysis; Springer: New York, NY, USA, 2016; pp. 421-463. 